\title{
Method of observing the action of magnets on liquids
}

\section{S.T. Morehead}

To cite this article: S.T. Morehead (1887) Method of observing the action of magnets on liquids, Philosophical Magazine Series 5, 24:149, 376-376, DOI: 10.1080/14786448708628116

To link to this article: http://dx.doi.org/10.1080/14786448708628116

曲 Published online: 29 Apr 2009.

Submit your article to this journal ๘

Џll Article views: 2

Q View related articles $\sqsubset$ 
latter should act directly on the needles of the galvanometer. In order to show this the author placed two insulated flames somewhat higher than the magnetic meridian, and connected these flames by wires at right angles to the meridian with the earth and the electrical machine respectively. The coils of the galvanometer should be either closed or altogether removed, otherwise the current divides in the coils; the metallic galvanometer with a bell-magnet gave a deflection of 5-7 divisions as soon as the machine was set to work. The distance of the flames was 920 millin. The direction of the current is changed when the current flows below the galvanometer, as required by Ampère's laws.-Journal of the Russian Physical and Chemical Society (7) xviii. 1886. From an abstract in Beiblätter der Physik, vol. xi. p. 369.

\section{METHOD OF OBSERVING THE ACTJON OF MAGNETS ON LIQUIDS. BY S. T. MOREHEAD.}

Some weeks ago one of my students, Mr. J. C. Child, and myself were working with a diamagnetic instrument, simply repeating well-known experiments. Plücker's method of observing the diamagnetism of liquids having failed in our hands to give satisfactory results, we hit upon a method which was new to us and which was very satisfactory. Into a g]ass tube of about four or five millimetres internal diameter a small quantity of liquid was introduced forming a short cylinder. This tube was placed horizontally at right angles to the line joining the poles of the magnet with the liquid nearly between the poles. When the current was turned on, the liquid was very evidently repelled. Water was repelled through a distance of about half a centimetre; wood-spirit through a greater distance. By moving the tube in the direction of its length the wood-spirit could be pushed any distance through the tube. The amount of motion is of course a function of the resistances due to adhesion and friction as well as of the repulsive force. The attraction of liquids is easily shown by the same method.

A single modification of the above plan of proceeding is to incline the tube slightly so as to make the liquid flow toward the poles. If the acquired velocity be not too great the magnet acts as a break to stop the motion. It is well to bend the tube up a little at each end to prevent the liquids from flowing out. This method is well adapted for projection so as to be seen by large audiences.-Silliman's American Journal, September 1887. 